\title{
The Effects of Heat Treatment on
} the Microstructure and Mechanical Properties of U-0.75 Wt.\% TI.

When printing a copy of any digitized SAND Report, you are required to update the markings to current standards. 
Issued by Sandia Laboratories, operated for the United States Energy Research and Development Administration by Sand ia Corporation.

\section{NOTICE}

This report was prepared as an account of work sponsored by the United States Government. Neither the United States nor the United States Energy Research and Development Administration, nor any of their employees, nor any of their contractors, subcontractors, or their employees, makes any warranty, express or implied, or assumes any legal liability or responsibility for the accuracy, completeness or usefulness of any information, apparatus, product or process disclosed, or represents that its use would not infringe privately owned rights.

\section{Printed in the United States of America Available from}

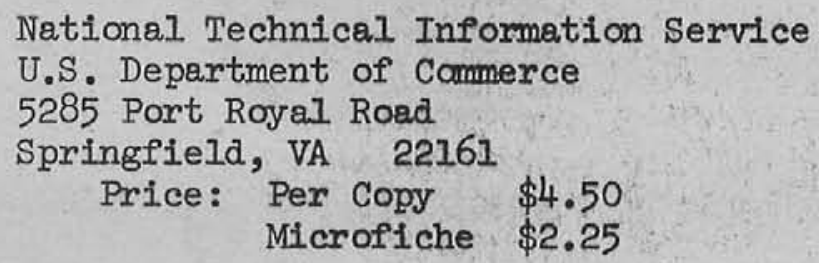


SAIND 75-0599

Unlimited Release

Printed June 1976

THE EFFECTS OF HEAT TREATMENT ON THE MICROSTRUCTURE

AND MECHANICAL PROPERTIES OF U-0.75 WT.\% TI

\author{
K. H. Eckelmeyer \\ Physical Metallurgy Division \\ Sandia Laboratories, Albuquerque, New Mexico 87115
}

\begin{abstract}
An extensive effort has been made at Sandia Albuquerque to characterize and understand the effects of heat treatment on the microstructure and mechanical properties of U-0.75 wt.\% Ti. This report constitutes a brief summary of that work. It has been written with the intention of providing a guide to heat treatment-microstructure-mechanical property relationships for those who are involved in the processing and application of U-0.75 wt.\% Ti. A compilation of related literature is included for those who desire an in-depth understanding of the physical metallurgy of this and other dilute uranium alloys.
\end{abstract}


Table of Contents

THE EFFECTS OF HEAT TREATMENT ON THE MICROSTRUCTURE AND MECHANICAI PROPERTIES OF U-0.75 WT.\% TI

$\begin{array}{lr}\text { Introduction } & \frac{\text { Page }}{} \\ \text { Effect of Cooling Rate on Microstructure } & 7 \\ \text { Effect of Cooling Rate on Properties } & 7 \\ \text { Effect of Aging on Microstructure } & 9 \\ \text { Effect of Aging on Properties } & 10 \\ \text { Effect of Cooling Rate on Response to Subsequent Aging } & 11 \\ \text { Additional Publications } & 11\end{array}$

Tables

Number $\quad$ Page

I Effect of Cooling Rate on Microstructure and Mechanical $\quad 14$ Properties

II Effect of Aging on Mechanical Properties $\quad 15$

III Effect of Cooling Rate on Aging Response 16

\section{Figures}

Number

$\underline{\text { Page }}$

1. A portion of the U-Ti equilibrium phase diagram (1). 17

2. The " $\beta+U_{2} T i "$ microstructure produced by cooling slower $\quad 18$ than $2^{\circ} \mathrm{C} / \mathrm{sec}$ (dark phase is $\mathrm{U}_{2} \mathrm{Ti}$ ). AIl specimens electroetched in a $1: 1$ solution of orthophosphoric acid:water.

3. The $\beta+\mathrm{U}_{2} \mathrm{Ti}$ (daris) plus $\alpha+\mathrm{U}_{2} \mathrm{Ti}$ (light) microstructure 19 produced by cooling at $\sim 5^{\circ} \mathrm{C} / \mathrm{sec}$. 


\section{Figures (Cont.)}

Page

4. Dark field transmission electron micrograph of the

$\alpha+\mathrm{U}_{2} \mathrm{Ti}$ structure produced by cooling at $\sim 8^{\circ} \mathrm{C} / \mathrm{sec}$ showing particles of $\mathrm{U}_{2} \mathrm{Ti}$ in an $\alpha$-matrix.

5. The $\alpha+\mathrm{U}_{2} \mathrm{Ti}$ (featureless) plus $\alpha^{\prime}$ martensite (lenticular)

21 microstructure produced by cooling at $\sim 45^{\circ} \mathrm{C} / \mathrm{sec}$.

6. The $\alpha^{\prime}$ martensite structure produced by cooling faster than $200^{\circ} \mathrm{C} / \mathrm{sec}$. Specimen anodized in a $1: 30$ solution of $\mathrm{NH}_{4} \mathrm{OH}$ : ethylene glycol and viewed using polarized light.

7. Transmission electron micrograph showing precipitates in the fully age hardened condition.

8. Partial decomposition of the $\alpha^{\prime}$ martensite to $\alpha+\mathrm{U}_{2} \mathrm{Ti}$ 24 resulting from aging at $450^{\circ} \mathrm{C} / 5$ hours. 


\section{Introduction}

The heat treatment of U- 0.75 wt. $\%$ Ti can best be understood by referring to the U-Ti equilibrium phase diagram shown in Figure 1. Above $723^{\circ} \mathrm{C}$, this alloy exists as a solid solution based on body-centered cubic $\gamma$-uranium. On cooling into the 723 to $667^{\circ} \mathrm{C}$ region the $\gamma$-phase decomposes to $\beta$-phase, a very dilute solid solution based on tetragonal $\beta$-uranium, plus an intermetallic compound, $\mathrm{U}_{2} \mathrm{Ti}$. On cooling below $667^{\circ} \mathrm{C}$, the $\beta$-phase transforms to essentially pure orthorhombic uranium while the $\mathrm{U}_{2} \mathrm{Ti}$ intermetallic remains unchanged.

Heat treatment of $U-0.75$ wt.\% Ti is based on the fact that these equilibrium transformations can be suppressed by rapid cooling, thus permitting a variety of microstructures with a wide range of mechanical properties to be obtained. These heat treatment-microstructure-mechanical property relationships have been the subject of extensive investigation at Sandia Laboratories. The results of these studies have been briefly summarized in this report in order to provide a guide for those involved in the processing of this alloy.

\section{Effect of Cooling Rate on Microstructure}

Cooling rate has a very pronounced effect on decomposition of the $\gamma$ phase and the resulting microstructures. When cooled at rates less than $2^{\circ} \mathrm{C} / \mathrm{sec}$, the $\gamma$-phase undergoes eutectoid decomposition to $\beta+\mathrm{U}_{2} \mathrm{Ti}$ as indicated on the equilibrium phase diagram. The resulting microstructure, shown in Figure 2, consists of alternate platelets of the $\beta$ and $\mathrm{U}_{2} \mathrm{Ti}^{\mathrm{i}}$ phases.

\footnotetext{
* All cooling rates are averaged over the $700^{\circ} \mathrm{C}$ to $600^{\circ} \mathrm{C}$ range where $\gamma$ phase decomposition occurs.
} 
The $\beta$-phase transforms to $\alpha$-phase on subsequent cooling to room temperature, but this produces no change in overall microstructural appearance, hence this structure will be referred to as " $\beta+\mathrm{U}_{2} \mathrm{Ti}$ ".

As cooling rate increases past $2^{\circ} \mathrm{C} / \mathrm{sec}$, the $\gamma \rightarrow \alpha+\mathrm{U}_{2} \mathrm{Ti}$ transformation begins to occur before the $\gamma \rightarrow \beta+U_{2}$ Ti reaction has gone to completion. This results in duplex microstructures such as the one shown in Figure 3 . The $\alpha+\mathrm{U}_{2} \mathrm{Ti}$ appears as a featureless microconstituent which etches much more slowly than $\beta+\mathrm{U}_{2} \mathrm{Ti}$. The individual $\alpha$ and $\mathrm{U}_{2} \mathrm{Ti}$ phases are much too finely divided to be resolved by optical microscopy, but transmission electron microscopy reveals that this microconstituent consists of rows of 200 to $500 \AA$ diameter particles of $\mathrm{U}_{2} \mathrm{Ti}$ in a matrix of $\alpha$-phase as shown in Figure 4. The volume fraction of $\alpha+U_{2}$ Ti increases at the expense of $\beta+\mathrm{U}_{2} \mathrm{Ti}$ as cooling rate increases. At a cooling rate of $8^{\circ} \mathrm{C} / \mathrm{sec}$ approximately $90 \%$ of the microstructure consists of $\alpha+\mathrm{U}_{2} \mathrm{Ti}$.

As cooling rate increases past $8^{\circ} \mathrm{C} / \mathrm{sec}$, a martensitic transformation $\gamma \rightarrow \alpha^{\prime}$ begins to occur before $\gamma \rightarrow \alpha+U_{2}$ Ti has gone to completion. This results in microstructures such as the one shown in Figure 5. The $\alpha^{\prime}$ martensite forms in lenticular plates which etch somewhat slower than the $\alpha+\mathrm{U}_{2} \mathrm{Ti}$. The transformation sequence occurring on cooling from the $y-$ field at rates of $8^{\circ} \mathrm{C} / \mathrm{sec}$ to $75^{\circ} \mathrm{C} / \mathrm{sec}$ is as follows. The $y \rightarrow \alpha+U_{2} \mathrm{Ti}$ transformation begins to occur along the $y$-grain boundaries in the $640^{\circ} \mathrm{C}$ to $620^{\circ} \mathrm{C}$ range. ${ }^{*}$ This continues unhindered until the $\gamma \rightarrow \alpha^{\prime}$ martensitic transformation begins at $615^{\circ} \mathrm{C}$. Below $615^{\circ} \mathrm{C}$, these two transformations compete for the remaining $\gamma$-phase. This sequence produces the microstructure

\footnotetext{
*At cooling rates of 8 to $12^{\circ} \mathrm{C} / \mathrm{sec}$, evidence of very small amounts of $\gamma \rightarrow$ $\beta+\mathrm{U}_{2} \mathrm{Ti}$ decomposition are occasionally found along some of the $\gamma$-grain boundaries
} 
shown in Figure 5. The continuous $\alpha+\mathrm{U}_{2} \mathrm{Ti}$ along the $\gamma$-grain boundaries was formed above $615^{\circ} \mathrm{C}$, i.e., prior to the start of the martensitic transformation. The finely partitioned $\alpha+U_{2} T i$ between the martensite plates was formed below $615^{\circ} \mathrm{C}$. As cooling rate increases, the volume fraction of $\alpha^{\prime}$ martensite increases at the expense of the $\alpha+\mathrm{U}_{2} \mathrm{~T} i$. The grain boundary $\alpha+\mathrm{U}_{2} \mathrm{Ti}$ disappears at a cooling rate of $75^{\circ} \mathrm{C} / \mathrm{sec}$, but small amounts of intermartensitic $\alpha+\mathrm{U}_{2} \mathrm{Ti}$ persist up to $200^{\circ} \mathrm{C} / \mathrm{sec}$.

When cooled at rates in excess of $200^{\circ} \mathrm{C} / \mathrm{sec}$, all of the $\gamma$-phase transforms to $\alpha$ martensite. This $100 \%$ martensitic microstructure is quite resistant to normal etching. The structure can be clearly revealed, however, by anodizing the polished surface and using polarized light illumination as shown in Figure 6.

\section{Effect of Cooling Rate on Properties}

The previously discussed effects of cooling rate on microstructure are reflected in variations in mechanical properties as shown in Table I. The $\beta+U_{2}$ Ti microstructure produced by cooling at $I^{\circ} \mathrm{C} / \mathrm{sec}$ has a hardness of $R_{c} 28$ to 30 , a yield strength of 475 to 525 MPa, and an elongation of 10 to $12 \%$.

Hardness increases with increasing cooling rate due to the presence of increasing amounts of $\alpha+\mathrm{U}_{2} \mathrm{Ti}$ in the microstructure. The much finer dispersion of $\mathrm{U}_{2} \mathrm{Ti}$ in the $\alpha+\mathrm{U}_{2} \mathrm{Ti}$ microconstituent is responsible for its being substantially harder than $\beta+U_{2} T i$. Hardness reaches a maximum of $R_{c} 43$ to 45 at a cooling rate of $8^{\circ} \mathrm{C} / \mathrm{sec}$ where $90 \%$ of the microstructure consists of $\alpha+\mathrm{U}_{2} \mathrm{Ti}$. The yield strength at this point is 775 to $825 \mathrm{MPa}$ and elongation is 6 to $8 \%$.

Hardness decreases with further increases in cooling rate due to the 
presence of increasing amounts of $\alpha^{\prime}$ martensite in the microstructure. The martensite is fairly soft because it is a substitutional solid solution of titanium in $\alpha$-uranium rather than an interstitial solution as in the case of very hard $\mathrm{Fe}-\mathrm{C}$ martensite. Structures containing more than $85 \%$ martensite produced by cooling rates in excess of $75^{\circ} \mathrm{C} / \mathrm{sec}$ have hardnesses of $R_{c} 35$ to 37 , yield strengths of 725 to $700 \mathrm{MPa}$, and elongations of 8 to $28 \%$. $^{*}$

Effect of Aging on Microstructure

The $\alpha^{\prime}$ martensite produced by rapid cooling of $\mathrm{U}-0.75 \mathrm{wt} . \% \mathrm{Ti}$ is highly supersaturated with titanium, hence it undergoes a series of changes during subsequent aging. These changes begin to occur at approximately $325^{\circ} \mathrm{C}$. Aging in the 325 to $450^{\circ} \mathrm{C}$ range for times of one to ten hours results in the formation of very fine precipitates in the $\alpha^{\prime}$ martensite. These precipitates are much too fine to be detected by optical microscopy, but they are easily revealed by transmission electron microscopy as shown in Figure 7 .

Aging at temperatures in excess of $450^{\circ} \mathrm{C}$ results in discontinuous decomposition of the martensite to the equilibrium $\alpha+\mathrm{U}_{2} \mathrm{Ti}$ phases. This decomposition begins primarily along the prior- $\gamma$-grain boundaries, as shown in Figure 8, and then extends into the interiors of the prior-y-grains. The decomposition product etches much more rapidly than the martensite due to its two phase nature, but the individual $\alpha$ and $\mathrm{U}_{2} \mathrm{Ti}$ phases are usually too finely divided to be resolved by optical microscopy.

\footnotetext{
* Powell and Condon (in Physical Metallurgy of Uranium Alloys, J. J. Burke, D. A. Colling, A. E. Gorum, and J. Greenspan, eds., Brook-Hill, to be published 1976) have shown that ductility is markedly dependent on hydrogen content. Solution heat treatment at $800^{\circ} \mathrm{C}$ for 4 hours or more in vacuum reduces hydrogen content to $<0.2 \mathrm{ppm}$ and results in a pronounced increase in ductility.
} 
Effect of Aging on Properties

The microstructural changes which occur during aging of the $\alpha^{\prime}$ martensite have marked effects on mechanical properties as shown in Table II. Substantial increases in hardness and yield strength result from the precipitation reaction occurring in the 325 to $450^{\circ} \mathrm{C}$ range. Aging at $450^{\circ} \mathrm{C}$ produces the highest hardness obtainable in this alloy, $R_{c} 48$ to 50. Hardness and yield strength decrease rapidly as the $\alpha^{\prime}$ martensite decomposes to the equilibrium $\alpha+\mathrm{U}_{2} \mathrm{Ti}$ phases at temperatures above $450^{\circ} \mathrm{C}$. Elongation tends to vary inversely with yield strength, but it is apparent that when compared at equivalent yield strengths, underaged specimens (aged below $450^{\circ} \mathrm{C}$ ) exhibit better ductilities than overaged specimens (aged above $450^{\circ} \mathrm{C}$ ).

\section{Effect of Cooling Rate on Response to Subsequent Aging}

The effect of subcritical quenching on aging response is shown in Table III. As discussed previously, the $\alpha^{\prime}$ martensite produced by very rapid cooling from the $\gamma$-field is amenable to subsequent age hardening because of its supersaturation with titanium. None of the phases formed on slower cooling by the diffusional $\gamma \rightarrow \beta+U_{2} T i$ or $\gamma \rightarrow \alpha+U_{2}$ Ti transformations are supersaturated, hence, they cannot be substantially age hardened. Specimens whose as-quenched structures consist of mixed $\alpha^{\prime}$ martensite and $\alpha+\mathrm{U}_{2} \mathrm{Ti}$, then, have slightly higher as-quenched hardnesses than fully martensitic specimens (by virtue of the fact that the $\alpha+\mathrm{U}_{2} \mathrm{Ti}$ microconstituent is harder than the $\alpha^{\prime}$ martensite), but they exhibit somewhat poorer responses to subsequent age hardening. Specimens whose microstructures are completely non-martensitic cannot be age hardened.

\section{Additional Publications}

Additional details relating to the physical metallurgy and mechanical 
properties of U-0.75 wt.\% Ti can be found in the following publications:

1. M. Hansen, Constitution of Binary Alloys, McGraw-Hill, 1958, p. 1239.

2. D. L. Douglass, "The Structure and Mechanical Properties of UraniumTitanium Martensites," Trans. ASM 53, (1960), 307.

3. R. Baschwitz, M. Colombie, and M. Foure, "Etude du Revenu des Phases Orthorhombiques Metastables D'Alliages Uranium-Titane 4.8 et 9.5 at.\% Titane," J. Nucl. Mat. 28, (1968), 246.

4. M. Linard, Study of Uranium-Titanium Alloys with a Low Titanium Content, Valduc Research Center, CEA Report R-4180, 1971.

5. D. J. Sandstrom, Some Mechanical Properties of Heat Treated Alloys of Uranium with Small Additions of Ti or Mo, Los Alamos Scientific Laboratory, Report IA-4781, 1971.

6. A. M. Ammons, Precipitation Hardening of Uranium-Titanium Alloys Containing Less Than 1.0 Weight Percent Titanium, Union Carbide Y-1? Plant, Report Y-1850, 1972.

7. R. J. Jackson, Effect of Humidity on Tensile Ductility of UraniumTitanium Alloys, Rockwell Rocky Flats Plant, Report RFP-2048, 1972.

8. C. A. Javorsky, U-0.83 wt.\% Ti Alloy: Cooling Rates of Gamma-Quenched Alloy, Resulting Microstructure and Response to Aging, Los Alamos Scientific Laboratory, Report IA-5442-MS, 1974.

9. N. J. Magnani, "The Effects of Environment Orientation and Strength Level on the Stress Corrosion Behavior of U-0.75 wt.\% Ti," J. Nucl. Mat. 54, (1974), 108 .

10. A. M. Ammons, "Precipitation Hardening in Uranium-Rich Uranium-Titanium Alloys," in Physical Metallurgy of Uranium Alloys, J. J. Burke, D. A. Colling, A. E. Gorum, and J. Greenspan, eds., Brook Hill, to be published, 1976. 
13. H. J. Saxton, "Fracture of Uranium Alloys," in Physical Metallurgy of Uranium Alloys, J. J. Burke, D. A. Colling, A. E. Gorum, and J. Greenspan, eds., Brook Hill, to be published 1976.

14. K. H. Eckelmeyer and F. J. Zanner, "Quench Rate Sensitivity in U-0.75 wt.\% Ti," submitted to J. Nucl. Mat., 1976.

15. K. H. Eckelmeyer and F. J. Zanner, "The Effect of Aging on the Mechanical Behaviors of U-0.75 wt.\% Ti and U-2.0 wt.\% Mo," to be published in J. Nucl. Mat., 1976. 
Table I

Effect of Cooling Rate on Microstructure and Mechanical Properties ${ }^{*}$

\begin{tabular}{|c|c|c|c|c|}
\hline $\begin{array}{c}\text { Cooling Rate } \\
\left({ }^{\circ} \mathrm{C} / \mathrm{sec}\right) \\
\end{array}$ & $\begin{array}{l}\text { Microstructure } \\
\text { (Volume \%) } \\
\end{array}$ & $\begin{array}{l}\text { Hardness } \\
\left(R_{C}\right) \\
\end{array}$ & $\begin{array}{l}0.2 \% \text { YS } \\
(\mathrm{MPa}) \\
\end{array}$ & $\begin{array}{c}\text { Elongation } \\
(\%)\end{array}$ \\
\hline 1 & $100 \% \beta+\mathrm{U}_{2} \mathrm{Ti}$ & 29 & 500 & 11 \\
\hline 5 & $\begin{array}{l}20 \% \beta+U_{2} \mathrm{Ti} \\
80 \% \alpha+\mathrm{U}^{2} \mathrm{Ti}\end{array}$ & 43 & 780 & 7 \\
\hline 10 & $\begin{array}{l}75 \% \alpha+U_{2}{ }^{T i} \\
25 \% \alpha^{\prime}\end{array}$ & 43 & 700 & 12 \\
\hline 20 & $\begin{array}{l}50 \% \alpha+\mathrm{U}_{2}^{\mathrm{Ti}} \\
50 \% \alpha^{\prime}\end{array}$ & 41 & 660 & 22 \\
\hline 50 & $\begin{array}{l}25 \% \alpha \alpha^{\prime}+U_{2} T i \\
75 \% \alpha^{\prime}\end{array}$ & 39 & 630 & 26 \\
\hline 200 & $100 \% \alpha^{\prime}$ & 35 & -- & -- \\
\hline
\end{tabular}


Table II

Effect of Aging on Mechanical Properties ${ }^{*}$

\begin{tabular}{|c|c|c|c|}
\hline $\begin{array}{l}\text { Aging Temp** } \\
\left({ }^{\circ} \mathrm{C}\right) \\
\end{array}$ & $\begin{array}{l}\text { Hardness } \\
\left(R_{c}\right) \\
\end{array}$ & $\begin{array}{l}0.2 \% \text { YS } \\
(\mathrm{MPa}) \\
\end{array}$ & $\begin{array}{c}\text { EIongation } \\
(\%)\end{array}$ \\
\hline Unaged & 35 & 700 & 14 \\
\hline 357 & 39 & 810 & 14 \\
\hline 380 & 41 & 890 & 15 \\
\hline 400 & 43 & 940 & 9 \\
\hline 456 & 50 & 1210 & 3 \\
\hline 500 & 45 & 990 & 3 \\
\hline 600 & 34 & 610 & 7 \\
\hline \multicolumn{4}{|c|}{$\begin{array}{l}\text { * All specimens solution heat treated at } 800^{\circ} \mathrm{C} \text { in } \\
\text { argon and quenched at } 75^{\circ} \mathrm{C} / \text { sec. }\end{array}$} \\
\hline \multicolumn{4}{|c|}{$\begin{array}{l}\text { *All specimens aged } 5 \text { hours } \\
{ }^{+} \text {Higher elongations can be obtained by vacuum } \\
\text { solution treatment to reduce hydrogen to }<0.2 \\
\text { ppm (Powell and Condon; in Physical Metallurgy } \\
\text { of Uranium Alloys, J. J. Burke, D. A. Colling, } \\
\text { A. E. Gorum, and J. Greenspan, eds., Brook Hill, } \\
\text { to be published 1976). }\end{array}$} \\
\hline
\end{tabular}


Table III

Effect of Cooling Rate on Aging Response

\begin{tabular}{|c|c|c|c|c|}
\hline \multirow{2}{*}{$\begin{array}{c}\text { Cooling Rate } \\
\left({ }^{\circ} \mathrm{C} / \mathrm{sec}\right) \\
\end{array}$} & \multirow{2}{*}{$\begin{array}{l}\text { Microstructure } \\
\text { (Volume } \%)\end{array}$} & \multicolumn{3}{|c|}{ Hardness $\left(R_{c}\right)$} \\
\hline & & Unaged & Aged & Increase on Aging \\
\hline 1 & $100 \% \beta+\mathrm{U}_{2} \mathrm{Ti}$ & 29 & 29 & 0 \\
\hline 5 & $\begin{array}{l}20 \% \beta+\mathrm{U}_{2} \mathrm{Ti} \\
80 \% \alpha+\mathrm{U}_{2}^{2} \mathrm{Ti}\end{array}$ & 43 & 42 & -1 \\
\hline 10 & $\begin{array}{l}75 \% \alpha+U_{2} \mathrm{Ti} \\
25 \% \alpha^{\prime}\end{array}$ & 43 & 44 & 1 \\
\hline 20 & $\begin{array}{l}50 \% \alpha+\mathrm{U}_{2} \mathrm{Ti} \\
50 \% \alpha^{\prime}\end{array}$ & 41 & 44 & 3 \\
\hline 50 & $\begin{array}{l}25 \% \alpha,+U_{2} T i \\
75 \% \alpha^{\prime}\end{array}$ & 39 & 47 & 8 \\
\hline 200 & $100 \% \alpha^{\prime}$ & 35 & 46 & 11 \\
\hline
\end{tabular}




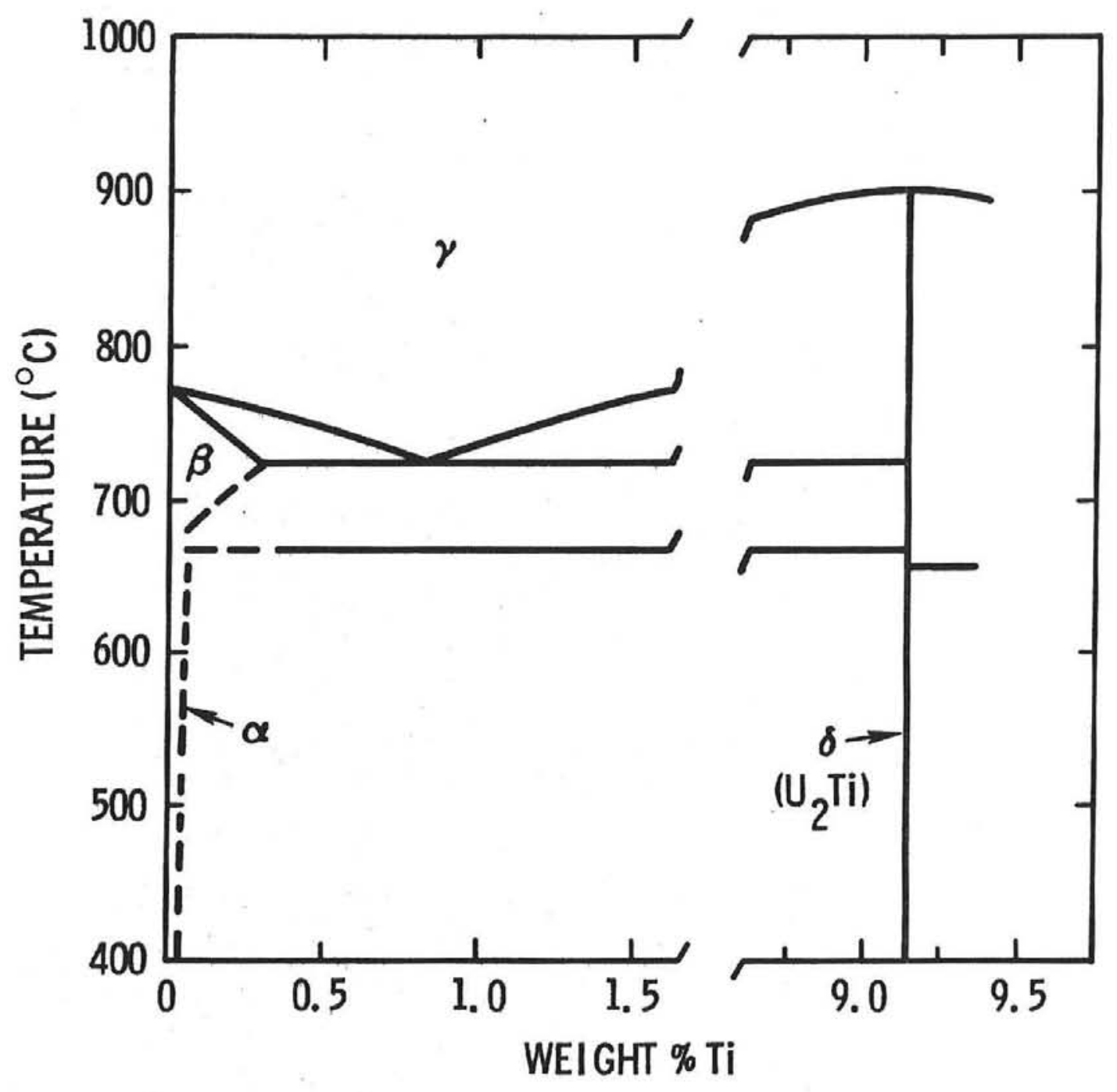

Figure 1: A portion of the U-Ti equilibrium phase diagram (1). 


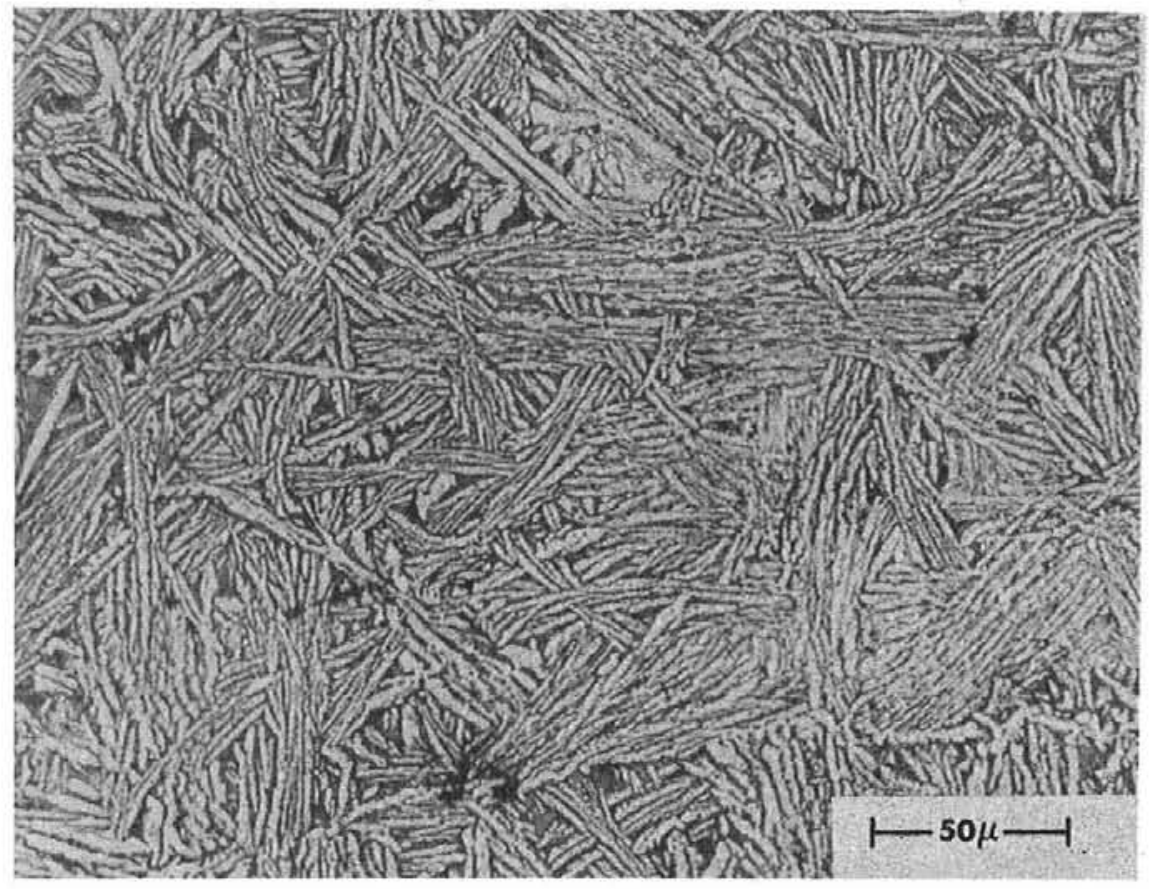

Figure 2: The " $\beta+\mathrm{U}_{2} \mathrm{Ti}$ " microstructure produced by cooling slower than $2^{\circ} \mathrm{C} / \mathrm{sec}$ (dark phase is $\mathrm{U}_{2} \mathrm{Ti}$ ). All specimens electroetched in a l:1 solution of orthophosphoric acid:water. 


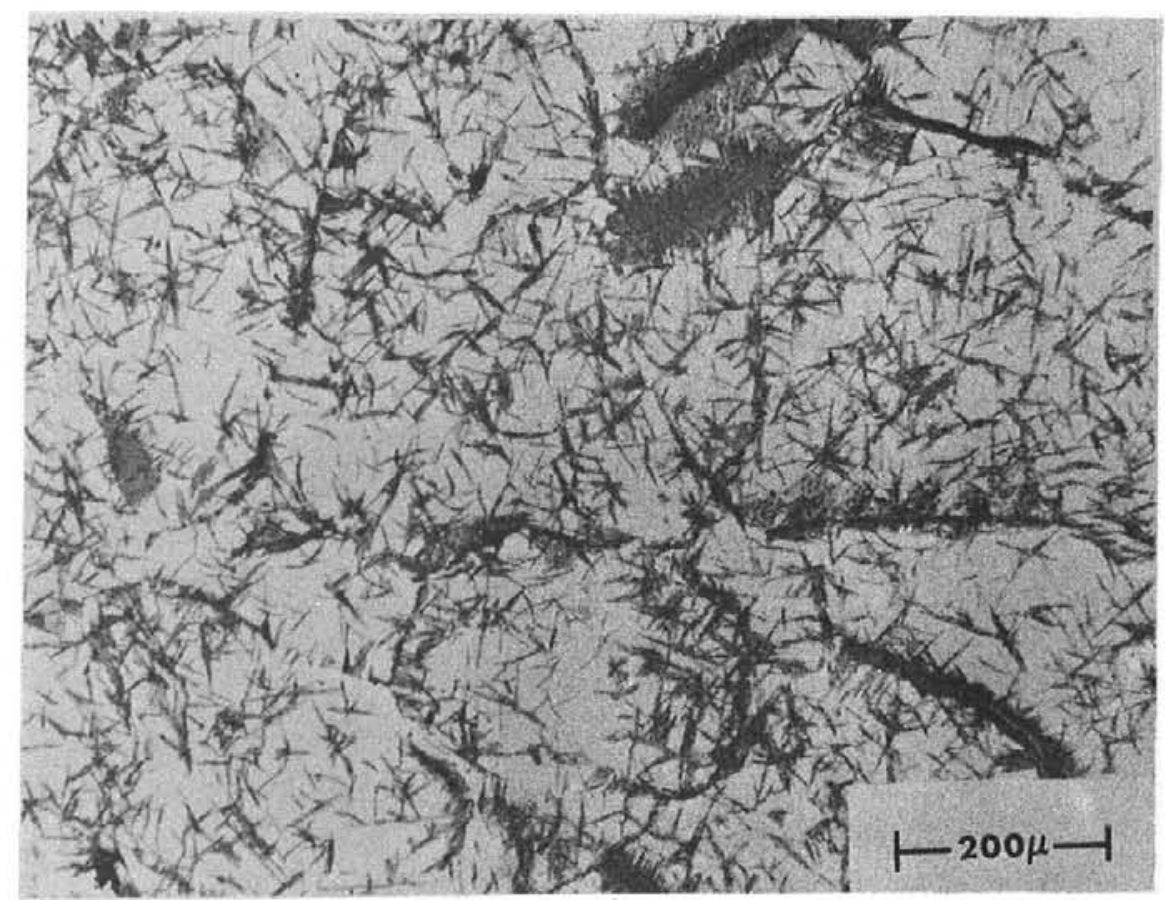

Figure 3: The $\beta+\mathrm{U}_{2} \mathrm{Ti}$ (dark) plus $\alpha+\mathrm{U}_{2} \mathrm{Ti}$ (light) microstructure produced by cooling at $\sim 5^{\circ} \mathrm{C} / \mathrm{sec}$. 


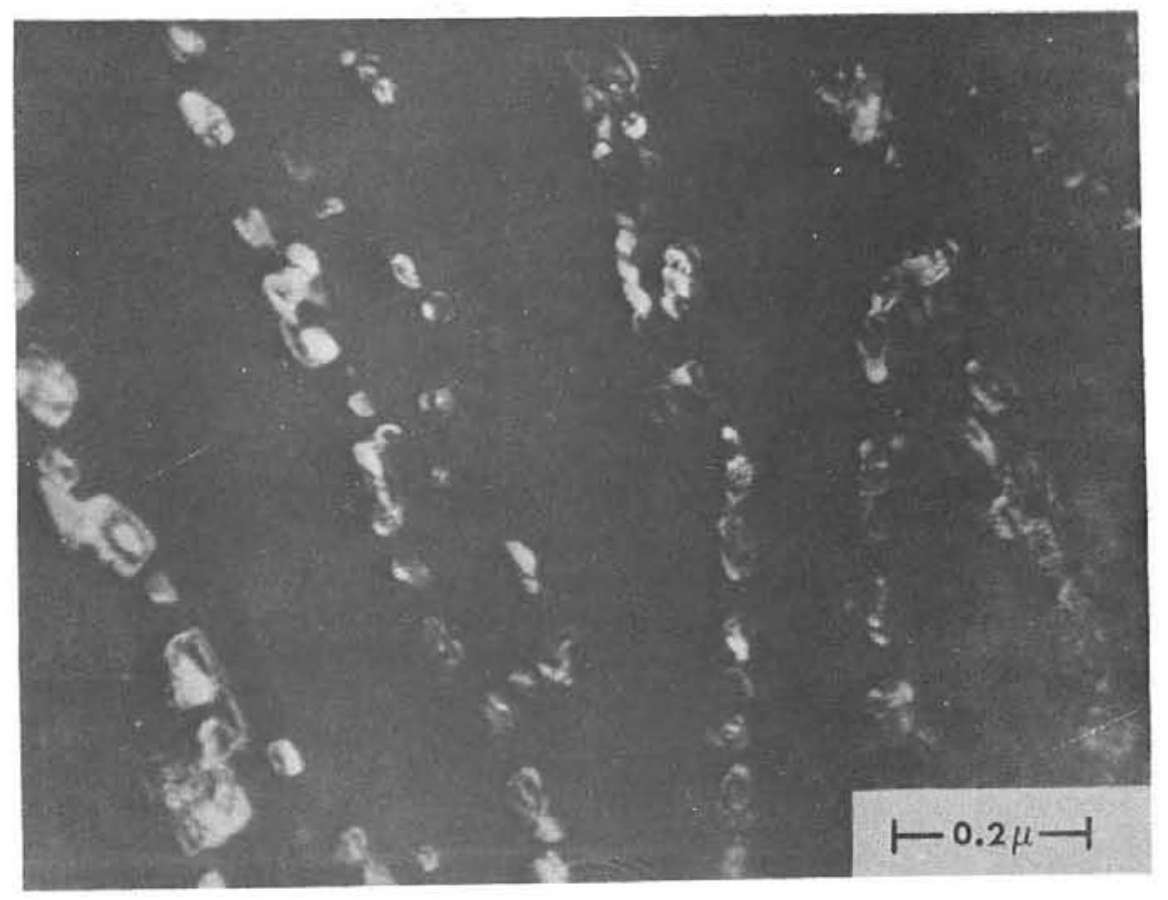

Figure 4: Dark field transmission electron micrograph of the $\alpha+\mathrm{U}_{2} \mathrm{Ti}$ structure produced by cooling at $\sim 8^{\circ} \mathrm{C} / \mathrm{sec}$ showing particles of $\mathrm{U}_{2} \mathrm{Ti}$ in an $\alpha$-matrix. 


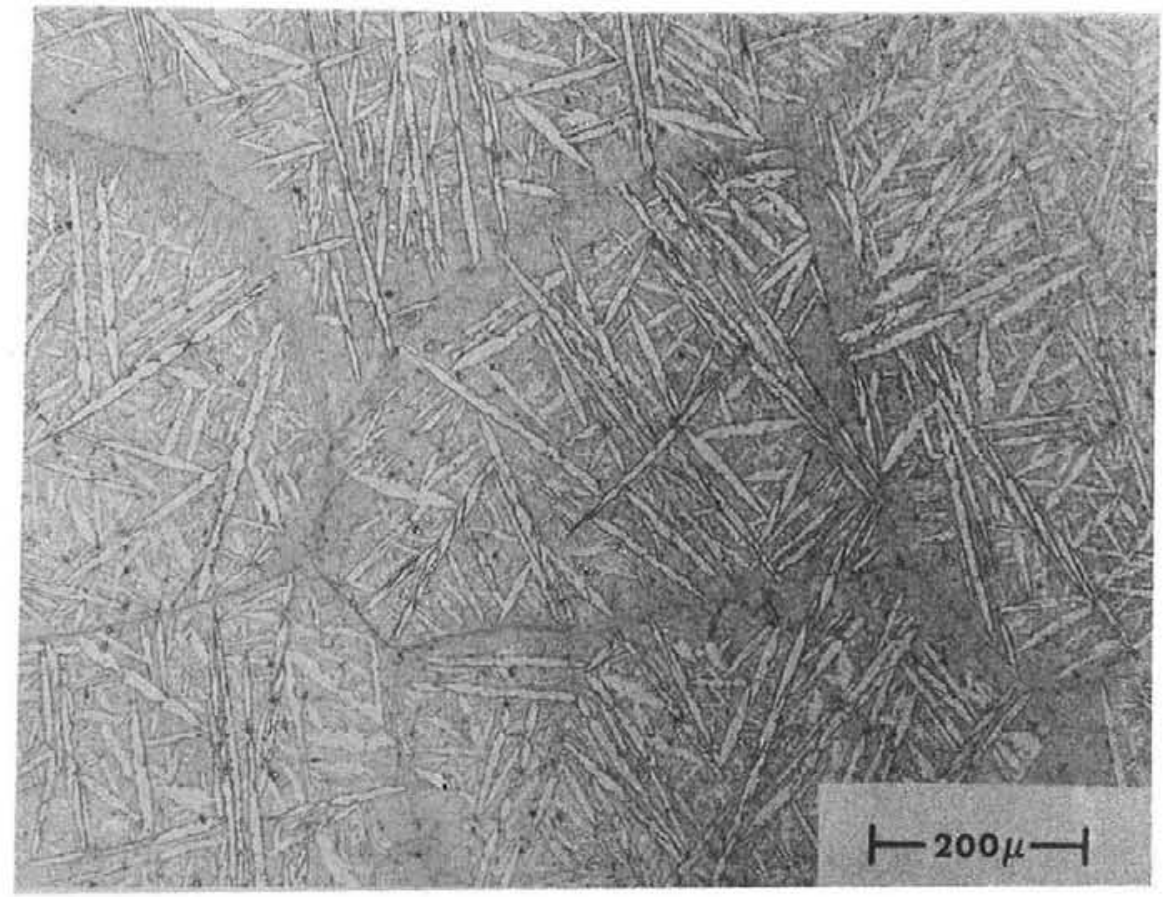

Figure 5: The $\alpha+\mathrm{U}_{2} \mathrm{Ti}$ (featureless) plus $\alpha^{\prime}$ martensite (lenticular) microstructure produced by cooling at $\sim 45^{\circ} \mathrm{C} / \mathrm{sec}$. 


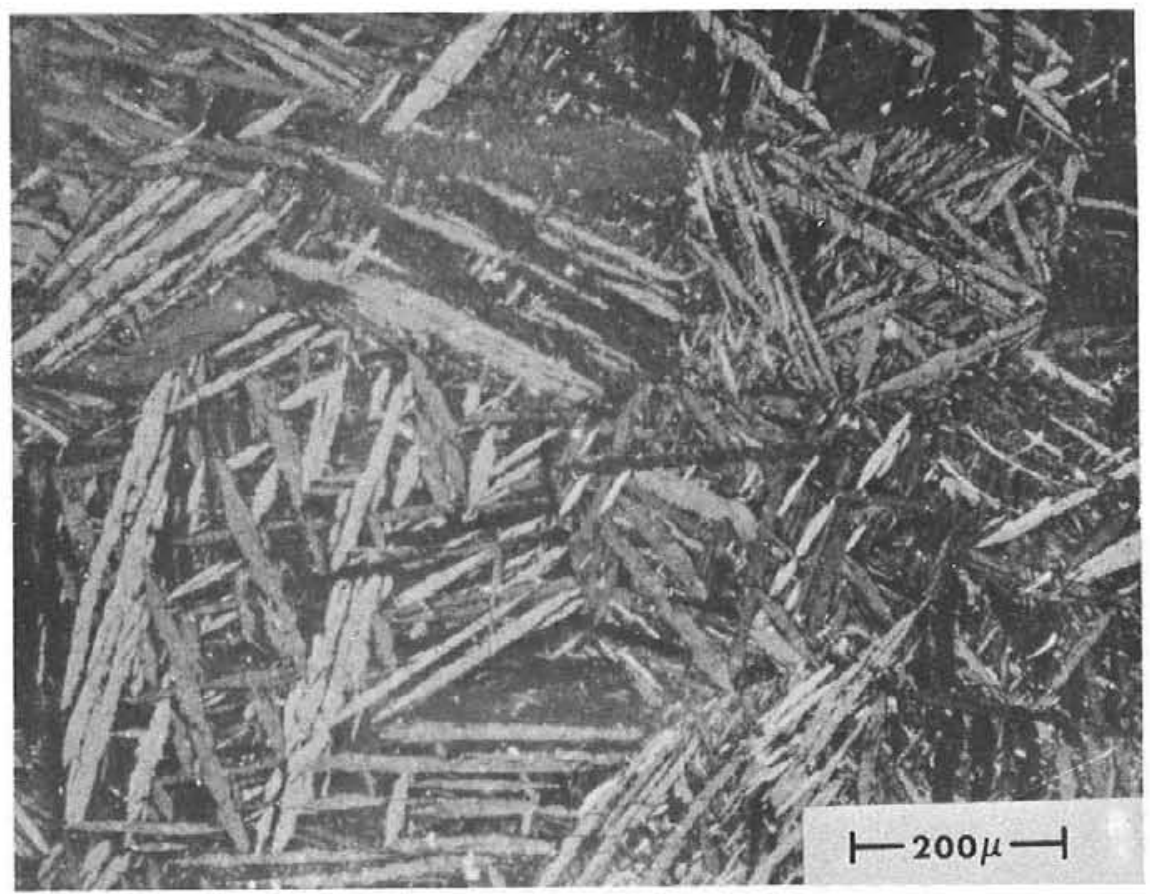

Figure 6: The $\alpha^{\prime}$ martensite structure produced by cooling faster than $200^{\circ} \mathrm{C} / \mathrm{sec}$. Specimen anodized in a 1:30 solution of $\mathrm{NH}_{4} \mathrm{OH}$ :ethylene glycol and viewed using polarized light. 


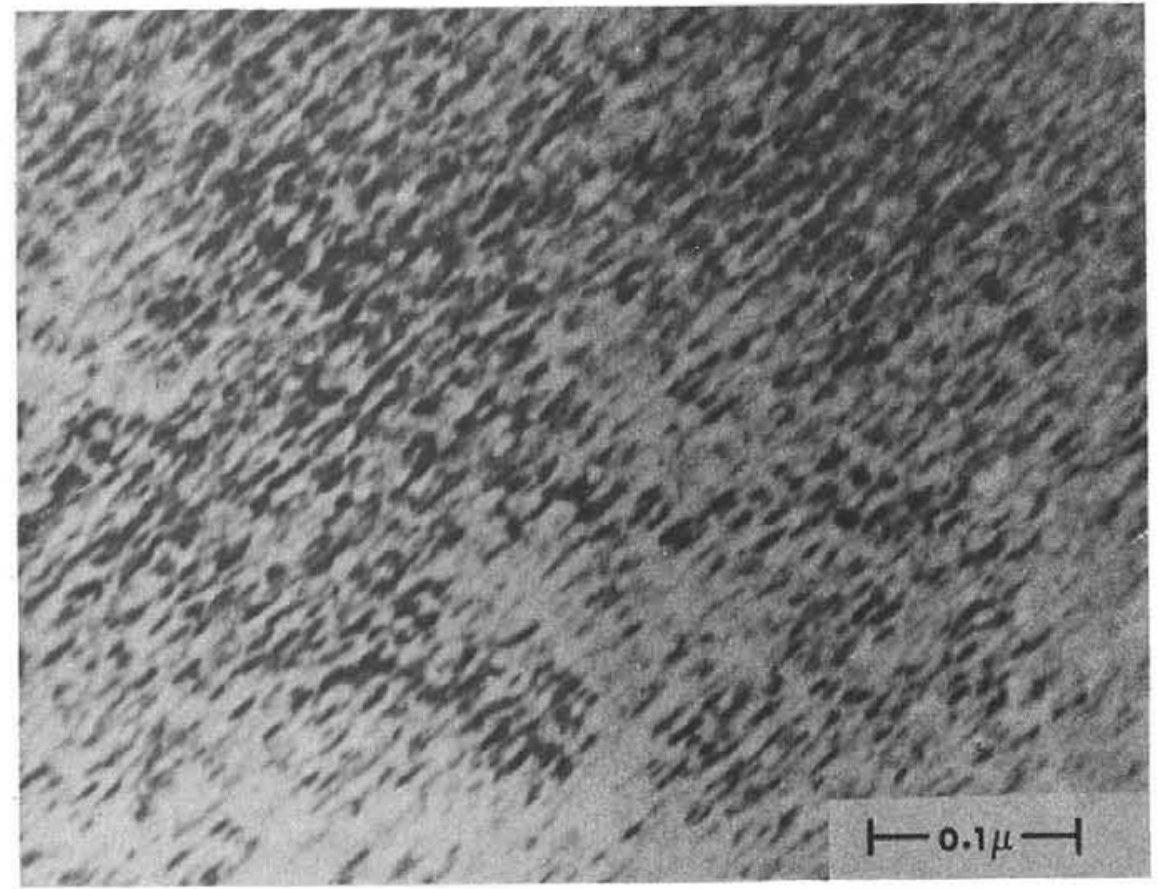

Figure 7: Transmission electron micrograph showing precipitates in the fully age hardened condition. 


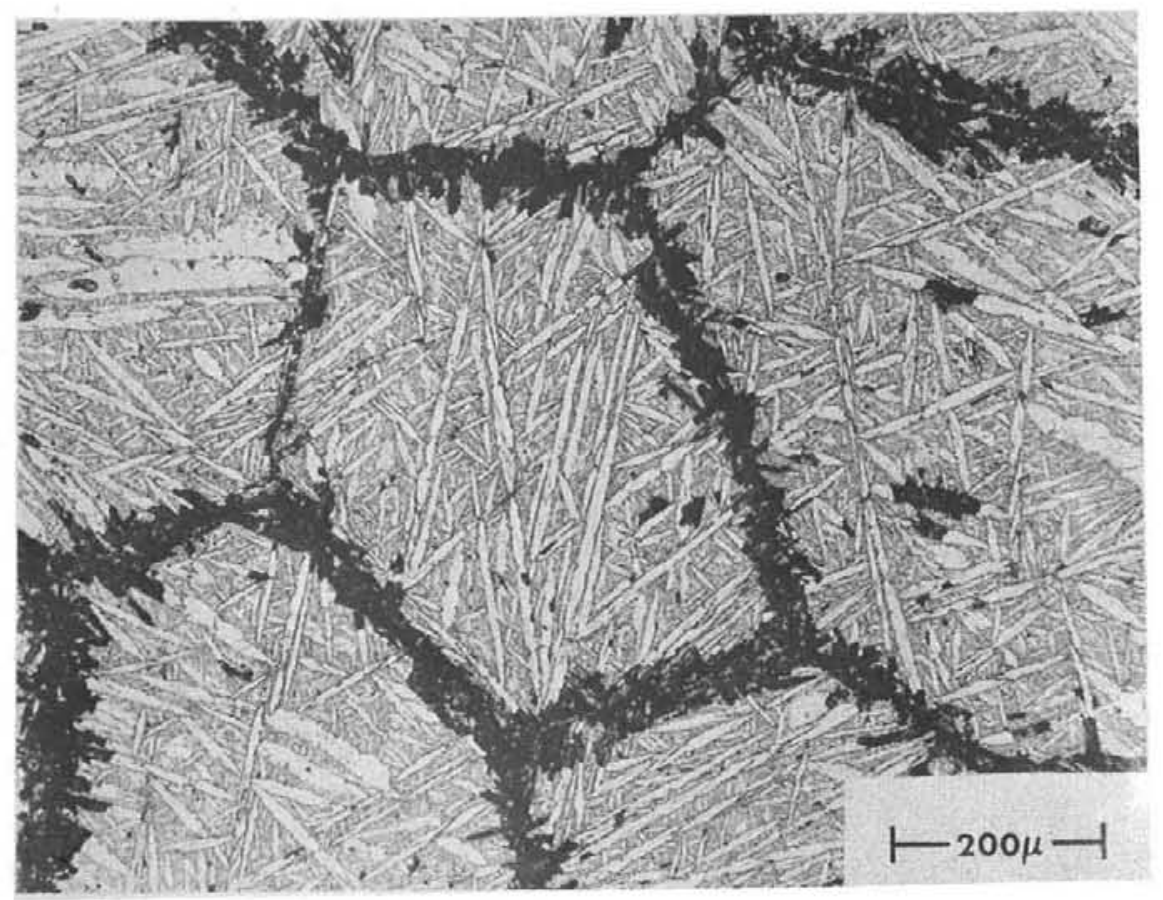

Figure 8: Partial decomposition of the $\alpha^{\prime}$ martensite to $\alpha+\mathrm{U}_{2} \mathrm{Ti}$ resulting from aging at $450^{\circ} \mathrm{C} / 5$ hours. 
Distribution:

Army Materials \& Mechanics Research Center

Watertown, MA 02172

J. Greenspan

F. J. Rizzitano

\author{
IASL (4) \\ J. E. Hockett \\ T. Jones \\ R. S. Kirby \\ D. J. Sandstrom
}

LLI (3)

L. W. Roberts

F. Fulton

D. Wood

$\mathrm{RRF}$ (2)

J. Boland.

R. J. Jacks on

$\mathrm{Y}-12(7)$

V. C. Hemperly

N. Jessen

J. M. Jones

J. W. Koger

T. C. Myhre

G. L. Powell

W. Snyder

E. W. Bloore

Ballistic Research Laboratory

AMXBR-TB

Aberdeen Proving Ground

Aberdeen, MD 21005

S. G. Fishman

Code $\mathrm{DG}-30$

U. S. Naval Surface Weapons Center

Dahlgren, VA 22448

I. Levy

National Lead Co.

Fernald, OH

A. R. Miller

New Mexico Institute of Mining and Technology

Socorro, NM 87801
G. A. Nyberg

Honeywell, Inc.

Twin City Arsenal

New Brighton, MN 55112

1000 L. C. Guynes (3)

For: A. E. Kay (AWRE)

D. Wright (AWRE)

B. J. Ward (AWRE)

1537 B. E. Bader

1563 W. E. Alzheimer

5000 A. Narath

Attn: 5100 J. K. Galt

5200 E. H. Beckner

5400 A. W. Snyder

5422 R. I. Coats 5700 J. H. Scott

Attn: D. J. Sasmor

5800 R. S. Claassen

Attn: 5810 R. G. Kepler

5820 R. L. Schwoebel

5840 D. M. Schuster

5830 M. J. Davis

At.tn: 5834 D. M. Mattox

5831 N. J. Magnani

5832 K. H. Eckelmeyer (25)

5832 J. P. Hickers on

5832 M. E. McAllaster (5)

5832 R. W. Rohde

5833 J. B. Duran

5833 M. R. Gutierrez

$5833 \mathrm{~J}$. I. Iedman

5833 F. J. Zanner

8157 H. Hanser

8167 D. Bohrer

Attn: J. Vieira

8312 D. R. Adolphson

8312 J. W. Dini

8312 H. R. Johns on

8312 M. W. Mote

8312 J. E. Smugeresky

8312 L. J. Weirick

8314 H. J. Sexton

8366 J. D. Gilson

3145 L. S. Ostrander (5)

3151 W. I. Garner (3)

For: ERDA/TIC (unlimited release)

8266 E. A. Aas (2)

ERDA/TIC (25)

R. P. Campbe11 - 3171-1 